Abstracta Iranica

Revue bibliographique pour le domaine irano-aryen

Volume 32-33 | 2013

Comptes rendus des publications de 2009-2010

\title{
Bruno Overlaet. Flower and Fire Altar. Fact and fiction on the Barm-i Dilak reliefs
}

\section{Barbara Kaim}

\section{(2) OpenEdition}

1 Journals

Édition électronique

URL : http://journals.openedition.org/abstractairanica/40567

DOI : 10.4000/abstractairanica.40567

ISSN : 1961-960X

\section{Éditeur :}

CNRS (UMR 7528 Mondes iraniens et indiens), Éditions de l'IFRI

\section{Édition imprimée}

Date de publication : 1 décembre 2013

ISSN : 0240-8910

\section{Référence électronique}

Barbara Kaim, «Bruno Overlaet. Flower and Fire Altar. Fact and fiction on the Barm-i Dilak reliefs », Abstracta Iranica [En ligne], Volume 32-33 | 2013, document 196, mis en ligne le 01 juillet 2016, consulté le 05 octobre 2020. URL : http://journals.openedition.org/abstractairanica/40567 ; DOI : https://doi.org/10.4000/abstractairanica.40567

Ce document a été généré automatiquement le 5 octobre 2020.

Tous droits réservés 


\title{
Bruno Overlaet. Flower and Fire Altar. Fact and fiction on the Barm-i Dilak reliefs
}

\author{
Barbara Kaim
}

\section{RÉFÉRENCE}

Bruno Overlaet. « Flower and Fire Altar. Fact and fiction on the Barm-i Dilak reliefs ». Iranica Antiqua, 45, 2010, p. 337-352.

Diverses interprétations avaient était proposées pour deux reliefs rupestres Sassanides à Barm-i Dilak, près de Šîrāz. L'A. ne discute pas l'iconographie générale ni la signification des reliefs, il se concentre sur deux éléments : un objet tenue par l'homme (Barm-i Dilak I) et un autel de feu qui, selon certains chercheurs, a été sculpté entre Bahram II et un dignitaire (Barm-i Dilak II). La présence de l'autel avait déjà été rejetée par De Waele et Vanden Berghe, l'A. a identifié les objets dans la main de rois comme la fleur d'un iris, peut-être l'Iris persicus.

\section{AUTEURS}

\section{BARBARA KAIM}

Université de Varsovie 